\title{
Talking about the Application of BIM in the Cost of Electric Power Engineering
}

\author{
LiuZhao, SongYan ${ }^{\mathrm{a}}$, YangHongwei, WangDongchao, XuNan, Zhao Binjun \\ State Administration of Economy and Technology, Hebei Electric Power Corporation, China \\ Shijiazhuang, Hebei 050000 \\ a892371853@qq.com
}

Key words: project costs, BIM, Modeling.

\begin{abstract}
BIM as a use of the establishment of the model to achieve the construction project cost of high-precision calculation, This article describes the basic connotation and development of BIM, and demonstrated the technology show in the power engineering cost control and dynamic strengths and future prospects.
\end{abstract}

\section{Introduction}

With the continuous improvement of the national economy, infrastructure is increasingly perfect, power construction is also rapid development. But behind the rapid development it has also bred many contradictions, raw material prices, the construction of a variety of factors of uncertainty, making it difficult to control the cost of electric power engineering. How to reasonably determine and control the project cost, so that the project cost growth control in a certain range determines the enterprise can achieve the highest efficiency.BIM technology can make a comprehensive forecast of the life cycle of the whole project, from the design process of resources, behavior, delivery of the three basic dimensions, given the design of the implementation of enterprise specific methods and practical content, so the cost of the entire power construction can be controlled effectively .

\section{BIM Overview}

BIM Basic Connotation. The full name of BIM is Building Information Modeling, based on the relevant information data of the construction project, the three-dimensional building model is established, and the real information of the building is simulated by digital information simulation.BIM expresses a construction project in digital form, through knowledge resource sharing, providing a reliable basis for all decisions in the facility from construction to dismantling the full life-cycle, at different stages of the project, by inserting different stakeholders in the BIM, extraction, update and modify the information to reflect the support and collaboration of their respective responsibilities.BIM applied to the project cost, is to achieve the project cost of fine management of one of the important content. Currently, BIM technology has carried out extensive research in cost management, cost control, but also in terms of the cost of the project has laid a solid foundation for all-round technical services.

BIM Development. BIM is derived from the United States in the 1970s, by the United States Georgia Tech Chuck Eastman for the first time. After 40 years of development, BIM has now formed a systematic, comprehensive, representative theory, in the construction industry, manufacturing and other areas set off a revolution. In the United States, the government has explicitly requested the company to achieve 3D-BIM in 2016 years ago in the United States, the government since 2003, the implementation of national 3D-4D-BIM plan; since 2007, all important projects through the BIM in Hong Kong, the government plans to use the BIM application as a design standard for all housing projects; in Singapore, the government set up a BIM fund in Hong Kong, the government plans to use BIM applications as a design standard for all housing projects in Hong Kong,; In 2015, over 80\% of the construction industry enterprises widely used BIM; in northern Europe, Norway, Denmark, Sweden and Finland and other countries, has produced Tekla, 
Solibri and other major construction information technology software manufacturers; in Japan, building information technology software industry sets up a national-level domestic solution software alliance. Foreign research on BIM technology in estimating project cost parameters is shown in Table 1[1].

Table 1 Cost Estimation Method and Cost Estimation Method

\begin{tabular}{|c|c|c|c|}
\hline Classification & Author & Method of Prediction & Case \\
\hline \multirow{10}{*}{$\begin{array}{l}\text { Parameter cost } \\
\text { forecast }\end{array}$} & $\begin{array}{l}\text { Choi In-Sung } \\
\text { (1999) }\end{array}$ & Multiple regression model & Office building \\
\hline & Emsley ( 2002) & Neural network model & Civil works \\
\hline & $\begin{array}{c}\text { Kan Phaobunjong } \\
\text { ( 2002) }\end{array}$ & Regression model & Office、school \\
\hline & $\operatorname{Li}(2005)$ & Simple regression model & Civil works \\
\hline & $\begin{array}{l}\text { Christian Stoy } \\
\text { ( 2007) }\end{array}$ & $\begin{array}{l}\text { Method of calculating } \\
\text { unilateral cost data }\end{array}$ & $\begin{array}{l}\text { Residential } \\
\text { building }\end{array}$ \\
\hline & $\begin{array}{c}\text { Ahmed A. } \\
\text { Shaheen ( 2007) }\end{array}$ & Fuzzy set model & Civil works \\
\hline & $\begin{array}{c}\text { Christian Stoy } \\
(2008)\end{array}$ & $\begin{array}{l}\text { Semi - logarithmic } \\
\text { regression model }\end{array}$ & $\begin{array}{l}\text { Residential } \\
\text { building }\end{array}$ \\
\hline & $\begin{array}{l}\text { Kim Hae-Gon } \\
\text { ( 2008) }\end{array}$ & Genetic algorithm & Office building \\
\hline & $\begin{array}{l}\text { Sevgi Zevnep } \\
\text { (2008) }\end{array}$ & Case - based reasoning & Office building \\
\hline & $\begin{array}{l}\text { Sae-Hyun Ji } \\
\text { ( 2011) }\end{array}$ & $\begin{array}{l}\text { Case - based reasoning and } \\
\text { genetic algorithm }\end{array}$ & $\begin{array}{l}\text { Residential } \\
\text { building }\end{array}$ \\
\hline \multirow{6}{*}{$\begin{array}{c}\text { Forecast of } \\
\text { engineering } \\
\text { quantity }\end{array}$} & $\begin{array}{l}\text { Surinder Singh } \\
\text { (1990) }\end{array}$ & $\begin{array}{l}\text { The method of calculating } \\
\text { the average of the data }\end{array}$ & $\begin{array}{c}\text { Steel - } \\
\text { concrete } \\
\text { building }\end{array}$ \\
\hline & $\begin{array}{l}\text { Lee Hak-ki } \\
\text { ( 1995) }\end{array}$ & Case - based reasoning & Office building \\
\hline & Choi Seok ( 1997) & Simple regression model & School \\
\hline & $\begin{array}{l}\text { I-Cheng Yeh } \\
\text { ( 1998) }\end{array}$ & Neural network method & $\begin{array}{c}\text { Reinforced } \\
\text { concrete } \\
\text { construction }\end{array}$ \\
\hline & $\begin{array}{l}\text { Tarek Hegazy } \\
\text { (1998) }\end{array}$ & Neural network method & Civil works \\
\hline & $\begin{array}{l}\text { Byung Joo } \\
(2010)\end{array}$ & $\begin{array}{l}\text { Case - based reasoning and } \\
\text { genetic algorithm }\end{array}$ & $\begin{array}{c}\text { Steel concrete } \\
\text { construction }\end{array}$ \\
\hline
\end{tabular}

The Development of BIM In China. Our country introduced this technology in 2005.With Autodesk enter the country, its promotion of software BIM, BIM concept was well known. In 2007, the Ministry of Construction issued the industry product standard "building object digital standard". Beginning in 2008, Shanghai logo building Shanghai Center decided to adopt BIM technology in the project, BIM technology in the domestic development began to accelerate. In 2011, China appeared at the first BIM Research Center (Huazhong University of Science and Technology). Beginning in 2012, government departments gradually began to contact and promote BIM, to 2016, housing urban and rural construction department issued 2016-2020 construction industry information development program clearly put forward BIM focus.

Now, BIM has been widely used in China, China's first high-rise - Shanghai Center, Beijing's first high-rise - China respect, the first high-rise building in Wuhan - Wuhan Center and other applications of BIM China project endless. Among them, the China Expo exhibition complex project proved: through the application of BIM can exclude $90 \%$ of the drawings error, reduce $60 \%$ rework, shorten the construction period of $10 \%$, improve project efficiency. At present, China's BIM 
cost software compared to other countries is not very mature, foreign Beck Technologies, Quantity Takeoff ( QTO), Vico, RIB iTWO, Visual Estimating and many more software still play an important role in China's software development.

\section{The Application Value of BIM in Electricity Cost}

BIM 's Accumulation and Sharing of Information in Project Lifecycle Management. In the general construction project, any construction-related information is in word, Excel and other forms of preservation. This kind of $2 \mathrm{D}$ form has brought a lot of trouble to the development, management and control of the project. The data can not be used intuitively at all stages, which can fundamentally limit the forecast of the project cost to the future. Most of these data is lost after using and can hardly keep. And through the BIM to build the building model, all the data will be reflected through the model, post-all changes, processing are carried out in this model, which make people's understanding of the project and understanding more intuitive and conducive to the integrity of information; It can also be more distant to save the data, is conducive to the accumulation of information to facilitate future access. Achieving the information of the terminal and BIM data background in the computer to complete the data expression, communication and sharing.

BIM's Accumulation and Sharing of Information in Project Life Cycle Management. BIM can create a database that belongs to a single project, or can create an associated database. By establishing a 5D relational database, you can obtain the same or similar models directly from the mass database, so you can quickly and accurately calculate the amount of work, improve the accuracy and efficiency of the calculation. Database-based BIM also supports real-time data updates, which reduces the cost of data due to delays, at the same time, because the data granularity of the BIM database reaches the component level, it can quickly provide the data information needed to support the project management, and effectively improve the construction management efficiency. BIM technology can automatically calculate the amount of engineering physical, this application is very common in our country, not only greatly improve the efficiency of the calculation, but also for the implementation of the project in all aspects of the control provided a guarantee.

BIM Achieves the Project Cost Information Management. With the rapid development of the Internet, more and more industries join the tide of the network, the construction industry is no exception. Internet for the cost of information management provides a good platform, and this platform can be achieved through BIM.BIM technology can really achieve that a network cable can be completed on the life cycle of the cost of control, response to the housing urban and rural construction of the national construction market, "a database of data, supervision of a network, management of a line" information requirements of the work. Based on the Internet platform under the project cost management, which will make it easy to manage for relevant departments, enterprises borrowed with qualifications, illegal construction and other bad behavior will be disappeared.

BIM Information is Intuitive and Efficient. Three-dimensional animation rendering, so that the whole project more intuitive display in front of everyone, giving a real and direct visual impact, what you see is what you want, whether it is 3D model of the 3D physical graphics, or project design, construction, operation, the entire construction process can be a well show, which facilitate the communication, discussion and decision-making. 

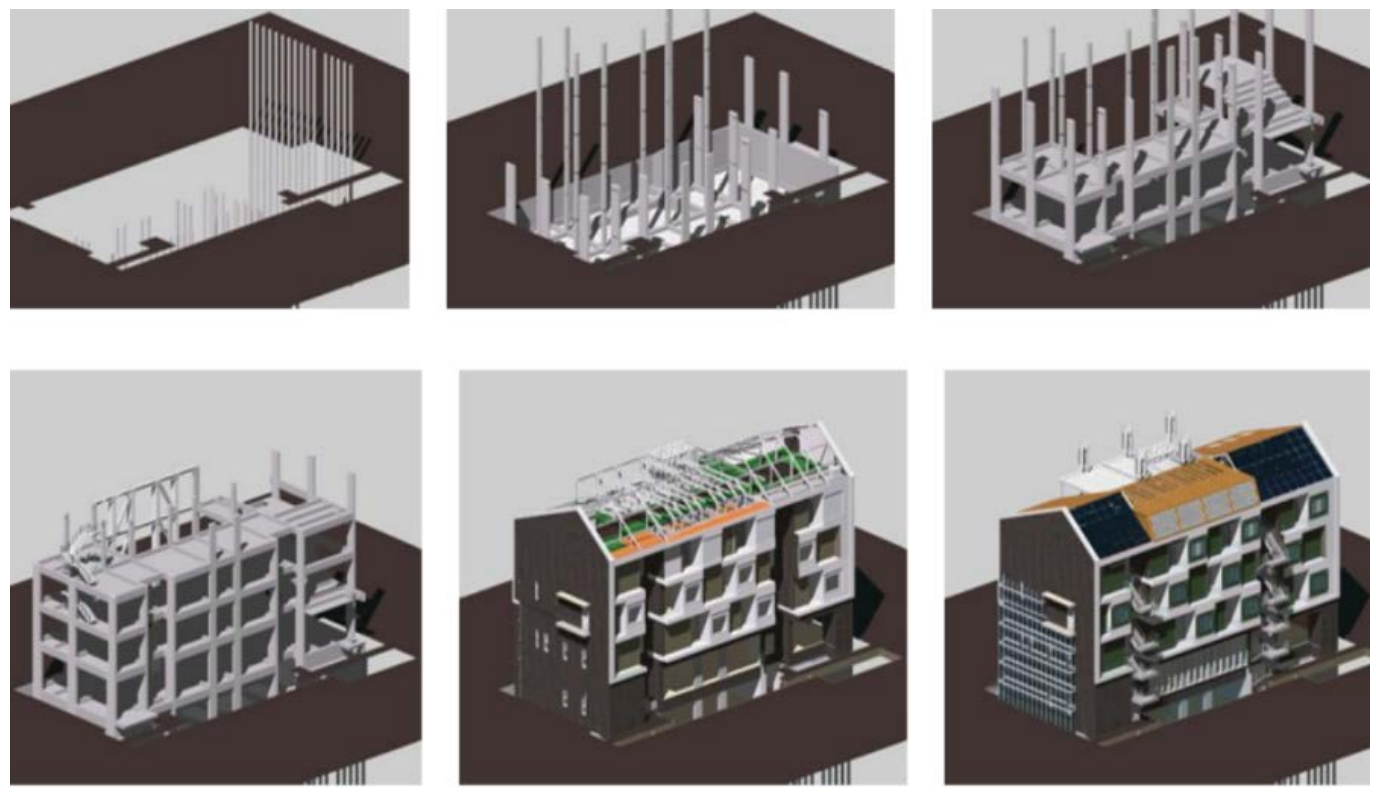

Figure 1

3D construction schedule simulation

\section{Application Prospect of BIM Technology}

Solve the Heavy Manpower Calculation. With the gradual improvement of BIM technology, cost engineers will be heavy and repeat the amount of work done completely to the computer, the computer can be based on instructions and the database model, and then calculate the corresponding amount of work. This method saves more time and effort for cost personnel to participate in more valuable work, such as project cost BIM consulting, project risk assessment forecast analysis, post-operation phase management, etc., they can also use the savings of time to prepare more accurate tender control price.

Synthesize More Information. In recent years, 3D-BIM-based project management is mainly used for planning, design phase of the program review, fire simulation, emergency evacuation energy analysis and operational management of the facility. In the future, developers will achieve BIM from 3D to $\mathrm{nD}$ change, that is not only the visual experience, but also add time information (4D) and cost information (5D) and many other factors. Through the collection of more factors, and then the calculation process, BIM greatly improves the accuracy of the calculation, and for the subsequent project cost management provides a strong support.

Will be a Wider Range of Applications. As China's introduction of BIM technology is relatively short, compared to other countries, China gap in terms of software development or the breadth of the application of a certain . After ten years of development, China has mastered more core technology, and the Ministry of Housing and Urban Construction of the "Twelve Five" plan clearly proposed to promote BIM collaborative work and other technical applications, universal visualization, parametric, three-dimensional model design, in order to improve design, reduce engineering investment, from design, procurement, construction, commissioning to operation of the whole process of integrated application. In the future, the breadth of BIM will increase, and the areas involved will be richer and extended to other categories of simulation and control.

\section{Conclusion}

With the constant innovation and development of BIM, BIM will be more and more used in the power construction industry. This technology to the project cost industry is not only a calculation method, but also a way of thinking and work innovation. It is undeniable that BIM technology can improve the accuracy of pre-forecasting, speed up the processing speed of information, facilitate the sharing of information and information transmission at all stages, and the convenience brought by BIM era is not limited to this. Currently on the market BIM software after another, but because of 
the lack of uniform standards, making a wide range of software applications limitations. Although there are many problems in varying degrees to hinder the development of BIM, BIM has a lot of room for development. I believe that in the near future, BIM technology in the cost of electricity projects will solve the existing problems to meet the different professional users, and even different industries user needs.

\section{References}

[1]H Edward Goldberg. Design data for construction: AEC industry progresses by evaluation construction costs and project management using BIM [J]. Cadalyst, 2006 (10): 45-47.

[2] LiuRui, XuYan: Application of BIM in Project Cost [J]. Project Management Technology, 2014(7):34-37

[3]Jae H C, BOSS, Jae Y C. Application of OLAP information model to parametric cost estimate and BIM [J]. Journal of Asian Architecture and Building Engineering,2011,10 (2) :319-326.

[4]Lin Wei. Research on Application of BIM Technology in Cost Management of Engineering Project. Architectural Knowledge [J].2016(6):197

[5]Franco K T Cheung, Jonathan Rihan, Joseph Tah, et al. Early stage multi-level cost estimation for schematic BIM models [J] . Automation in Construction,2012,27 (7): 67-77. 